\title{
New subscripts for old rescripts: the Vallicelliana fragments of Justinian Code Book VII )
}

In diesem Beitrag werden die zwei erhaltenen Blătter eines Manuskripts aus dem 11. Jahntundert publiziert, das eine ungekürzte Fassung des Codex Iustinianus enthielt (Carte Vallicelliane XII.3). Die beiden Blătter enthalten C. 7,64,2-9 und C. 7,71,8,4-7,72,6 und bieten uns elf neue oder jedenfalls verbesserte Subskriptionen zu den darin enthaltenen Reskripten.

This article publishes the two surviving folios from an eleventh century manuscript of an unabbreviated Justinian Code (Carte Vallicelliane XII.3), covering CJ 7,64,2-9 and 7,71,8,4-7,72,6, and providing eleven new or revised subscripts for the rescripts therein.

I. Introduction. - II. The fragments and their text. - III. Corrected text and translation. IV. The headings and the subscripts.

\section{Introduction:}

In their book on the fate of the Justinianic codification in the early middle ages, Charles Radding and Antonio Ciaralli have drawn attention to recently identified fragments of a Justinian Code manuscript in the Biblioteca Vallicelliana in Rome $^{1}$ ). Two folios used for binding were separated and conserved in the 1980s and recognized as coming from a Justinian Code written in Beneventan script (Carte Vallicelliane XII.3). The earliest references in print to the identification of these folios were by Virginia Brown in 1994 and Roger Reynolds in $1996^{2}$ ). However, the significance of the identification has only now been demonstrated by Radding and Ciaralli. They date the fragments to the second half of the eleventh century, suggesting that they may have been copied at Monte Cassino. Given that they generally date the manuscripts of the Justinianic 'revival' slightly later that was previously assumed, this manuscript is indeed very early during that process. What marks it out, however, is its nature. In the Radding/Ciaralli scenario, the Code was effectively dormant from the early seventh to the early eleventh centuries ${ }^{3}$ ). Then some time shortly after 1000 , Lombard jurists developed an interest in it again and created trimmed-down versions of the Code, containing only the material that seemed most useful to them. They did not, however, create a long-lasting static Epitome Codicis, of the type previous scholarly orthodoxy envisaged for the early mediaeval Code. The Lombards' interest

") I should like to thank the following for their advice and assistance: Michael Crawford, Carlotta Dionisotti, Charles Radding, and Benet Salway. I should also like to thank the Biblioteca Vallicelliana and its director, Dr. Maria Concetta Petrollo, for kind permission to publish the text and pictures of the two folios, as well as Mario Setter, the photographer who furnished me with the images.

') C. Radding/A. Ciaralli, The Corpus Iuris Civilis in the Middle Ages: Manuscripts and Transmission from the Sixth Century to the Juristic Revival (Brill's Studjes in Intellectual History 147), Leiden 2007, 86-87 and plate 11.

${ }^{2}$ ) V. Brown, A second new list of Beneventan manuscripts (III), in: Mediaeval Studies 56 (1994) 337; R. Reynolds, Gratian's Decretum and the Code of Justinjan in Beneventan script, in: Mediaeval Studies 58 (1996) 287-288. Vallicelliana D. 49 provides the only other CJ fragments in the library (G. Dolezalek, Repertorium manuscriptorum veterum Codicis Iustiniani, Frankfurt 1985, vol. 1, 381).

${ }^{3}$ ) For their view of the Code, see Radding/Ciaralli, Corpus Iuris Civilis (n. 1) ch. 5; cf. C. Radding, Reviving Justinian's Corpus: the case of the Code, in: P. Andersen et al. (eds.), Law Before Gratian: Law in Western Europe c. 500-1100, Copenhagen $2007,35-50$. 
rapidly blossomed, so that the abbreviated versions were speedily re-expanded, so fast indeed, that by the early twelfth century the reintegrated medieval Code (minus the Greek of course) was in existence. Emblematic of this is the earliest surviving manuscript of this process, the Pistoriensis. Previously often thought to be tenth-century, it is now dated to the mid eleventh, and with its many constitutions added in the margin or even pasted-in on slips of parchment, it shows the lively activity of re-expansion. One thing that did not happen, however, was that, as the Code reached its nearly full form again, any scribe simply decided to copy out an intact Code. Perhaps copyists preferred to copy as much as possible from a text written in a more familiar near-contemporary script, only taking from the late antique codices still in existence material otherwise missing, rather than copying them out complete.

Into this eleventh century pattern of an epitomized and then rapidly re-expanded Code, come the Vallicelliana fragments. These clearly represent a different, non-Lombard, approach, for they come from an intact and complete Code. Despite the fact that we have only these two folios, their nature is apparent. First, each gives a complete run of constitutions in the correct order (folio 1: CJ 7,64,2-9; folio 2: CJ 7,71,8-7,72,6), in contrast with the partial and disordered sequences of the earliest epitome manuscripts $^{4}$ ). Secondly, each preserves a full set of subscripts, these being the feature of the Code constitutions most speedily dropped from manuscripts elsewheres). Most surviving subscripts are usually attested in only one or two manuscripts. Since the sections covered in the fragments originally contained no Greek, it is impossible to tell whether the Vallicelliana codex in its complete form contained the Greek, although in an eleventh century context that may seem unlikely. In any case, the Vallicelliana fragments are not an early example of the revival, but rather a coda, being a rare and late surviving example of the complete Code tradition, which was otherwise superseded by the re-expanded but still deficient medieval Vulgate. The only comparable manuscript source is the Würzburg fragments, which, while also surviving as only two folios, similarly represent the remains of an intact Code. They were written in romanesca, probably copied in or near Rome in the third quarter of the eleventh century ${ }^{6}$ ). Our view of the nature of the Vallicelliana and Würzburg fragments is not dependent on the Radding/Ciaralli reconstruction of the Code's history. The traditional view has been that the Epitome Codicis, Greekless, lacking the last three books, and shorn of much of its other remaining material, had come into existence earlier in the middle ages, with a gradual re-expansion from the tenth century onwards ${ }^{7}$ ). This still leaves a

4) Thus of CJ 7,64,2-9, P gives only 7, and L 7, 10 and 5; for 7,71,8-72,6, P and $\mathrm{L}$ give only 5 . C, R, M, however, give both sequences complete.

s) The Vallicelliana folios contain twelve subscripts at the appropriate points, with only one missing, probably from the trimming of the parchment $(\mathrm{CJ} 7,71,8)$. By contrast, only three of these subscripts were previously known (CJ 7,64,5 and 7; and 7,72,5).

6) See R. Weigand, Fragmente des römischen Rechts in der Universitätsbibliothek Würzburg, ZRG RA 105 (1988) 784-785, with the dating of A. Ciaralli, Produzione manoscritta e trasmissioni dei testi di natura giuridica fra XI e XII secolo: due esempi, in: V. Colli (ed.), Juristische Buchproduktion im Mittelalter, Kolloquium 25. bis 28. Oktober 1998, Frankfurt am Main 2002,90-92. I discuss these fragments and their subscripts in more detail elsewhere in this volume, p. 423-439.

7 ) For a classic account, see M. Conrat, Geschichte der Quellen und Literatur des römischen Rechts im frühen Mittelalter, Leipzig 1891, 53-57. 
pronounced contrast between the other abbreviated Code manuscripts of the eleventh century deriving from a Lombard context and two apparently complete Codes written in scripts associated predominantly with southem Italy.

II. The fragments and their text:

From the point of view of the text of the Justinian Code, the most important feature of the Vallicelliana fragments is their preservation of subscripts not known from elsewhere (nine new out of twelve in all). Otherwise, the text is largely consistent with the known tradition and offers few significant variant readings. However, it seems best here to provide a complete edition of the text for the sake of clarity. Note that both folios were trimmed for re-use, so that a line at the top or bottom may be missing or preserve only the upper or lower tips of the letters. It seems that each page originally had 23 or 24 lines of text in two columns. The trimming has also cut away the outer edge, so that the rectos have lost the ends of lines in column two, the versos the beginnings of lines in column one. Given the brevity of many of the rescripts, the scribe is frequently able to start a column with a new constitution (Folio $1 \mathrm{r}$ col. 2, $1 \mathrm{v}$ cols. 1 and 2, Folio $2 \mathrm{r}$ col. 2, 2v col. 2). Each constitution begins with an elaborate " $\Gamma$ " (either for imp[erator/es] or id [em]) with an elongated descender.

The writing on folio $2 \mathrm{r}$ is hard to read, with much of the ink rubbed off, especially in the second column. Since part of that has also been cut away, it is impossible in some cases to distinguish between the lacunae for missing ink as opposed to missing parchment.

Only one title is given $(7,72)$, written in red at the top of Folio $2 \mathrm{r}$ col. 2. Since of the first line only the lower traces survive, there is no indication as to whether it was given a number.

The individual constitutions, however, are numbered. In total seven such numbers survive, the others being lost in the trimming of the parchment. Thus III is written against $C J 7,64,3$, then, since by error no number was written against $C J 7,64,4$, the next number is IIII against $C J$ 7,64,5, with a knock-on effect also for the next two visible numbers, VII and VIII for CJ 7,64,8-9. There appears to be a I written by $C J 7,72,1$, although nothing can be seen where one would expect a number for $C J 7,72,2$. The next visible numbers are $\mathrm{V}$ and $\mathrm{VI}$ written correctly against $\mathrm{CJ}$ $7,72,5-6$.

The only annotations on the fragments occur on folio $1 \mathrm{r}$, and these are not legal scholia but religious 'doodles'. Between the two columns against lines 4 and 5 there appears to be the rather mysterious sentence 'Alendarum peccator deficit ab impetratis'; further below against lines 7 and 8 there is 'in presentia'. Above and below col. 1 line 21 , there are 'maria aue' and 'aue maria gratie plena'.

In the text, the following conventions are used: italic for the expansion of the Beneventan abbreviation signs; and square brackets [ ] for manuscript lacunae, where the parchment has been trimmed. Punctuation follows the manuscript, principally being interpuncts in headings and subscripts. The missing text has been easily restored from the well-known Code tradition. I have used Krüger's editio maior of $1877^{8}$ ).

8) P. Krüger, Codex Iustinianus, Berlin 1877, repr. Goldbach, 1998. 
Fig. 1: Carte Vallicelliane XII.3 Folio 1r $(=\mathrm{CJ} 7,64,2-5)$

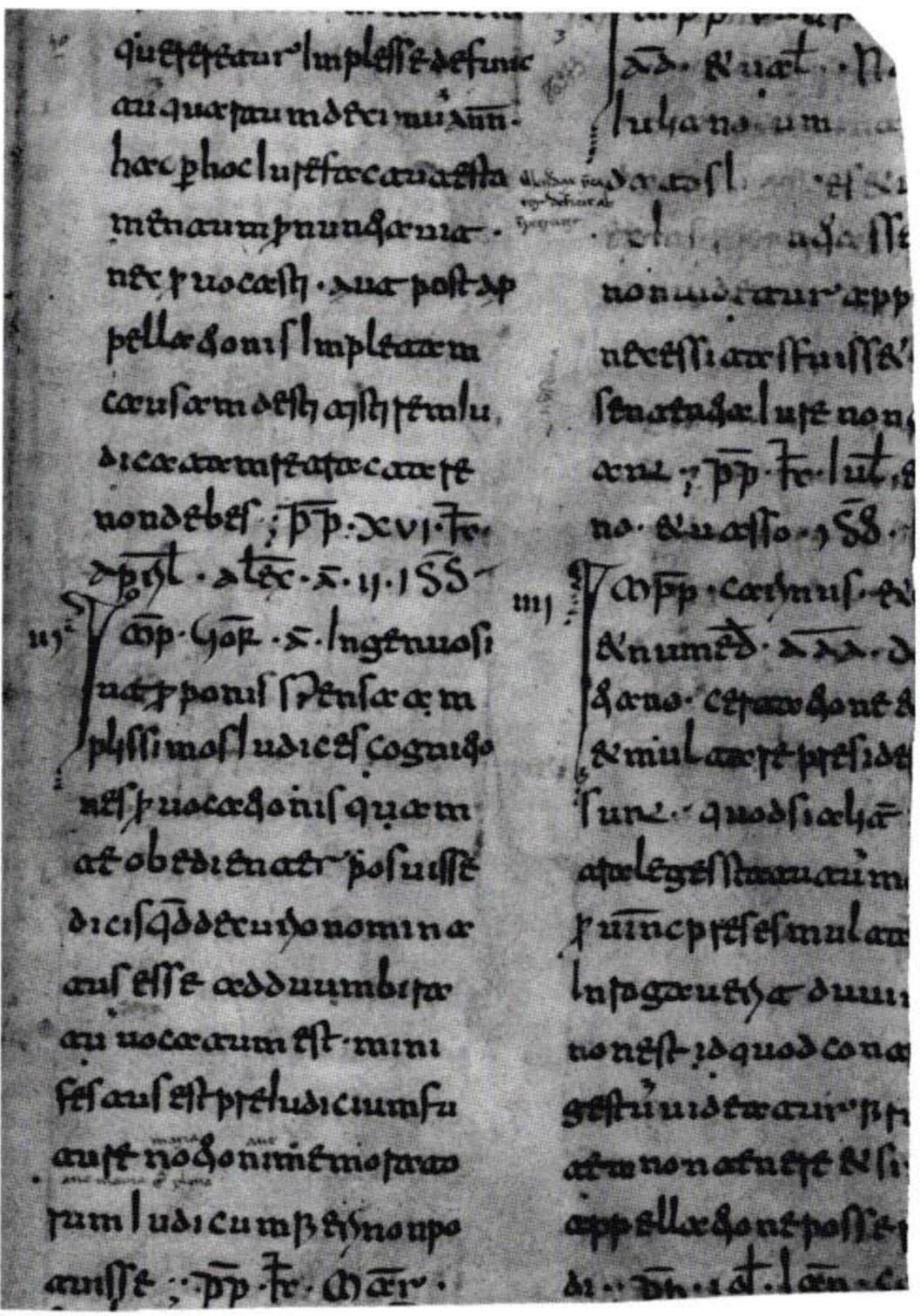

Photographed by Mario Setter 
Fig. 2: Carte Vallicelliane XII.3 Folio 1v (= CJ 7,64,6-9)

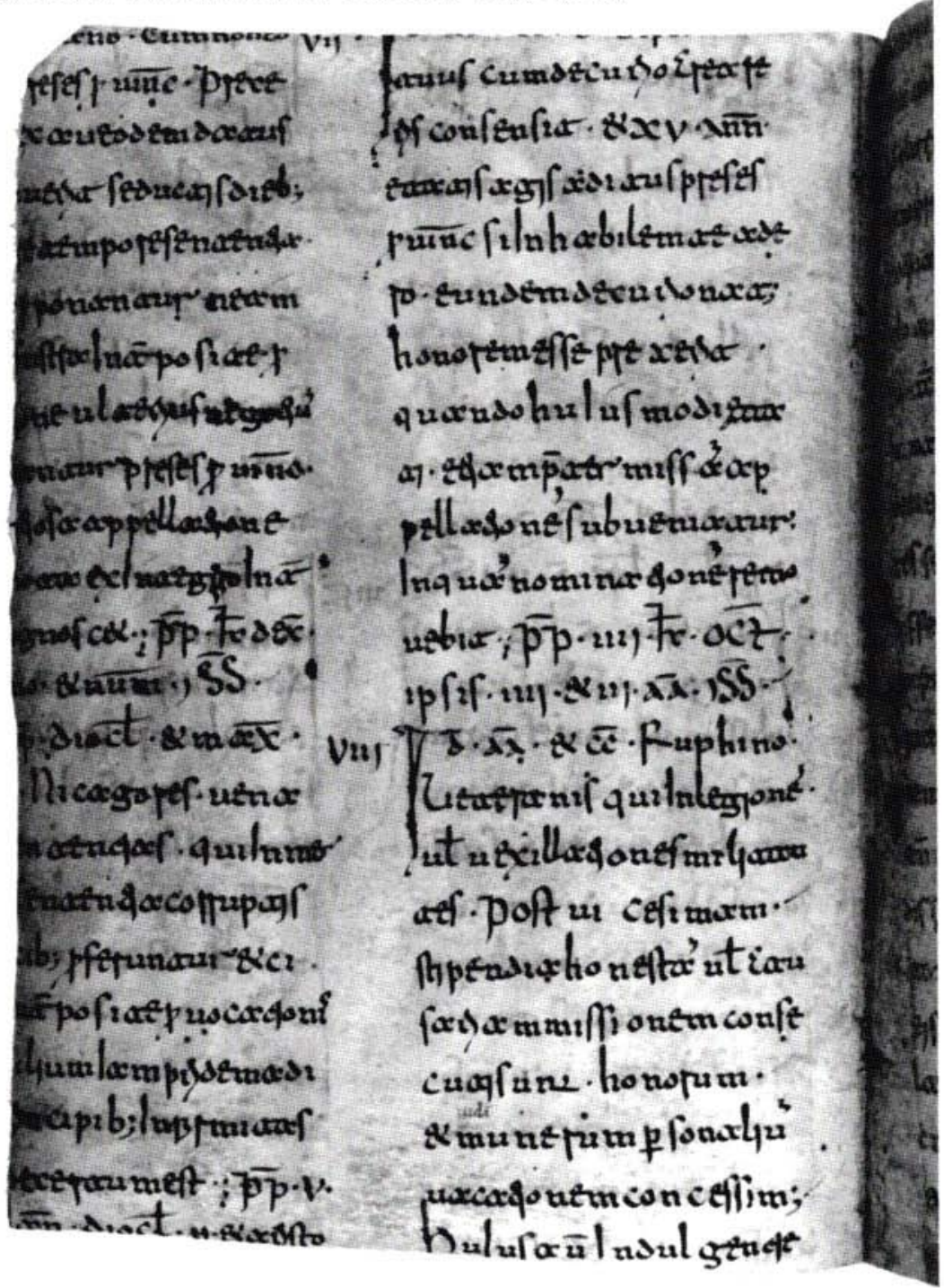


Fig. 3: Carte Vallicelliane XII.3 Folio $2 \mathrm{r}(=\mathrm{CJ} 7,71,8,4-7,72,2)$

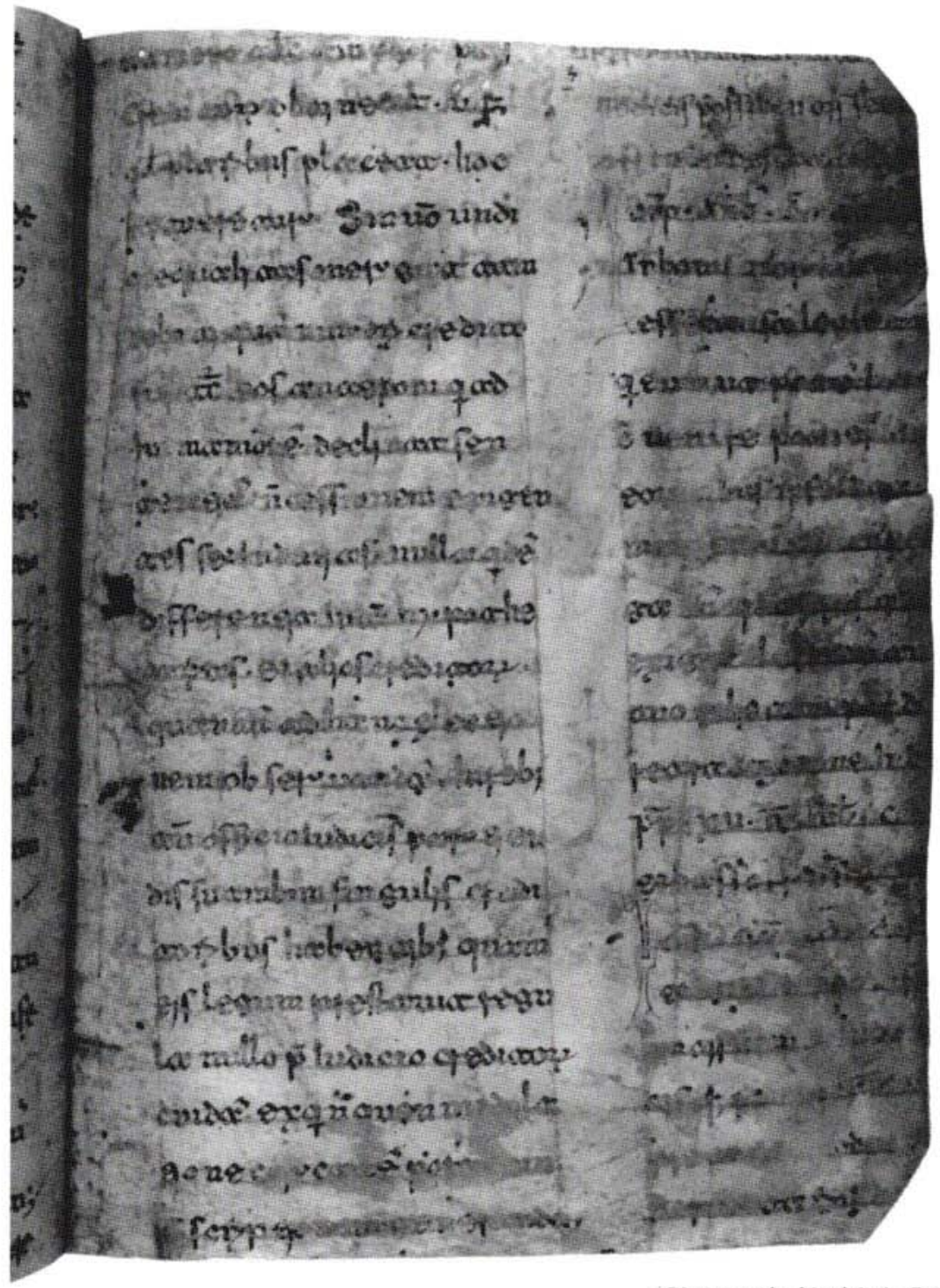

Photographed by Mario Setter 
Fig. 4: Carte Vallicelliane XII.3 Folio $2 v(=C J 7,72,2-6)$

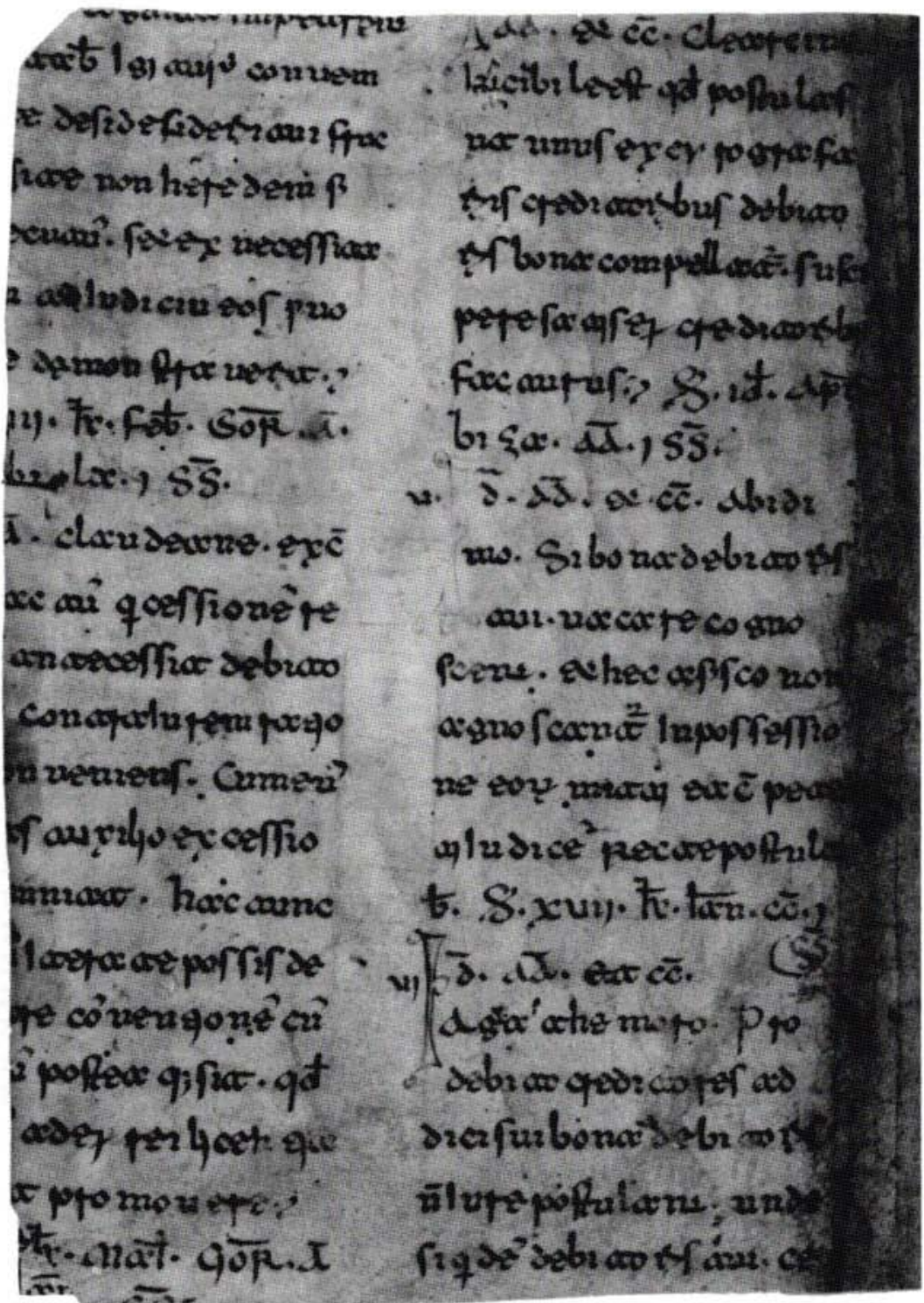


Folio $1 \mathrm{r}(=\mathrm{CJ} 7,64,2-5)$

Col. 1
Q[uod si cum] de etate quereretur Implesse defunctum quartum decimum annum hac per hoc Iure factu testamentum pronuntiauit . nec prouocasti - aut post appellationis Impletam causam destitisti rem Iudicatam retractare non debes ; PP $\cdot \mathrm{XVI} \cdot \mathbf{k}$. april $\cdot$ alex $\cdot \mathbf{a} \cdot$ ii $\cdot$ conss

III Imp · GOR - a - Ingenuo si ut proponis spensa amplissimos Iudices cognitiones prouocationis quam te obedienter posuisse dicis quod decurio nominatus esse ad duumbiratum uocatum est minifestus est preludicium future notioni memoratorum Iudicum fieri non potuisse ; PP - $\mathbf{k} \cdot$ Mar $\mathrm{S}[\mathrm{a}] \mathrm{b}$ [ino \& uenusto con]ss
Col. 2

Impp - Valer[ et Gallien]

aa - et $\mathrm{Val} \cdot \mathrm{No}[\mathrm{b} \mathrm{C}]$ Iuliano cum ma[gistratus] datos Iudices et $u$ [num] ex his pronuntiasse [proponas] non uidetur app[ellandi] necessitas fuisset [cum] sententia lure non $t$ [ene]ant ; PP · $\mathbf{k} \cdot$ Iul $\cdot \mathrm{e}$ [milia]no et uasso conss .

IIII Impp carinus - et c[arus] et numed $\cdot$ aaa $\cdot$ do[mi]tiano $\cdot$ certatione et [fine] et multare presides [pos]sunt - quod si aliter [et con]tra leges statutun mo[dum] prouincie preses multa[m uobis] Inrogauerit duuiu[m] non est id quod contr[a ius] gestum uideatur firm[ita]tem non tenere et $\sin [\mathrm{e}]$ appellatione posse $r$ escin]di ; PP · id · Ian · ca[ro] [et carino conss]

$$
\text { Folio IV (=CJ 7,64,6-9) }
$$

\section{Col. 1}

[V d aaa germ]ano - Cum non eo

2 [die quo p]reses prouincie Prece[pit iude] $x$ au eodem datus [pronunti]auerit seductis diebus [alienio]re tempore sententia [dedisse] proponantur, ne am[bages] fustra Interposite pro[uoca]tione ulterius negotium [protrah]antur preses prouincie [supersti]tiosa appellatione [sub]mota ex Integro Inter [uos c] ]ognoscet ; PP · $\mathbf{k}$ dec . [cari]no et num - conss .

[VI Imp]p - diocl - et max [a] Nicagores - uena[les s]ententias - qui In mer-

\section{Col. 2}

VII I[d aa constantio Si pater] tuus cum decurio Creareris consensit - et XV' annos etatis agis aditus preses prouincie si Inhabilem te adero - eundem decurionatus honorem esse prexerit . quando hulusmodi aetati - etiam pretermissam appellationem subueniatur, inquam nominationem remouebit ; PP - iiii $\cdot \mathbf{k} \cdot \mathrm{OCT}$. ipsis - iiii - et iii - aa ' conss $\cdot$

VIII Id - aa - et cc - Ruphino · Ueteranis qui In legionem uel uexillationes militan- 
[cedem] sententi a corruptis [iudi]cibus proferuntur et ci[tra i]nterposite prouocationis [aux]ilium lam pridem a di[uis p]rincipibus Infirmitas [esse] decertum est ; PP - V . [k I]an - diocl - ii · et aristo[bulo conss ] tes $\cdot$ Post ui cesimam stipendia honestam uel Causariam missionem consecuti sunt honorum . et munerum personalium uacationem concessimus. Hulus autem Indulgentic [nostrae tenore remunerantes]

Folio $2 \mathrm{r}$ (= CJ 7,71,8,4-7,72,2)

\section{Col. 1}

numero tunc amplior pars

creditorum obtineat ut

quod pluribus placeat $\cdot$ hoc

statueretur - (5) Sin vero undi-

que equalitas mergat tam

debiti quam numeri credito-

rum tunc eos anteponi qui ad

humaniorem declinat sen-

tentiam non cessionem exigen-

10 tes set Indutias (6) nulla quidem

11 differentia inter hypothe-

12 carias et alios creditorum

13 quantum ad hanc electio-

14 nem obseruandam In rebus

15 autem officio Iudicis partien-

16 dis suam bim singulis credi-

17 toribus habentibus quam

18 eis legum prestauit regu-

19 la (7) nullo preludicio creditorum

20 cuidam ex quinquennii dila-

21 tione circa temporalem prescriptionem generando

[subscript?]

[subscript?]

\section{Col. 2}

De bonis auctoritate Iudicis possidentis seu u[enum]dandis et de separationi[bus] Imp $\cdot$ ant $\cdot \mathbf{a} \cdot$ attic [e] In bonis mortui poti[orem] esse causam legata[riorum] qui eum utpote here[dem] conuenire potuerunt [quam] eorum quibus ipse legau[it] manifestum est cum pri[us le]gatum quasi es alienum? exigitur legatum au[tem a mor]tuo relictum post de[biti] retractatione Indu[citur] $\mathbf{P P} \cdot \mathbf{x u} \cdot \mathbf{k} \cdot \mathbf{I u l} \cdot \mathbf{c}[$ entiano ?] et basso $\cdot$ conss Imp Gor A Aris[toni] Est iurisdictionis [tenor pro]mptissimus indem[nita]tisque remedium ed[icto?] pretoris credito[ribus] hereditariis de[monstratum] [ut quotiens separationem] [bonorum postulant] 


\begin{tabular}{|c|c|c|c|}
\hline \multicolumn{4}{|c|}{ Folio $2 v(=C J 7,72,2-6)$} \\
\hline & Col. 1 & & Col. 2 \\
\hline 1 & [causa ]cognita impetrent & [IIII & I[mpp Diocl et Max $]$ \\
\hline 2 & [Preop]tabis Igitur conueni- & & aa $\cdot$ et cc $\cdot$ Clearcine \\
\hline 3 & [en]te desidesiderii tui fruc- & & Incibile est quod postulas \\
\hline 4 & [tum] si te non heredem fi- & & ut unus ex cyrografa- \\
\hline 5 & [dem s] ecutum - set ex necessita- & & riis creditoribus debito- \\
\hline 6 & [te]m ad Iudicium eos prouo- & & ris bona compellatur susci- \\
\hline 7 & [car]e damonstrauerit ; & & pere satis eius creditoribus \\
\hline 8 & {$[\mathrm{PP} \cdot] \mathrm{iii} \cdot \mathbf{k} \cdot \mathbf{f e b} \cdot \mathrm{GOR} \cdot \mathbf{a} \cdot$} & & facturus ; S - id - apri . \\
\hline 9 & [et a]biola conss . & & biza $\cdot$ aa $\cdot$ conss $\cdot$ \\
\hline 10 [III & Id] a claudeane $\cdot$ ex con- & V & Id $\cdot$ aa $\cdot$ et cc $\cdot$ Abidi- \\
\hline 11 & [tr]actum qui cessionem re- & & mo $\cdot$ Si bona debitoris \\
\hline 12 & [rum] antecessit debito- & & tui - uacare cogno- \\
\hline 13 & [rem] contra Iurem ratio- & & scent et hec a fisco non \\
\hline 14 & [nem c]onueniens - Cum eum & & agnoscantur In possessio- \\
\hline 15 & [equit]as auxilio excessio- & & ne eorum mitti ea conpeten- \\
\hline 16 & [nis] muniat $\cdot$ hac tunc & & ti Iudicem Recte postula- \\
\hline 17 & [dem]um iterate possis de- & & bis $\mathrm{S} \cdot \mathrm{xuii} \cdot \mathrm{k} \cdot \operatorname{Ian} \cdot \mathrm{cc} \cdot \mathrm{con}-$ \\
\hline 18 & [sider]are conuentionem cum & VI & Id $\cdot$ aa et $\mathrm{cc}$. \\
\hline 19 & [tant]um postea quesit quod & & Agathemoro $\cdot$ Pro \\
\hline 20 & [preside]m ad eius rei licentia & & debito creditores ad- \\
\hline 21 & [debea]t promouere ; & & dici sui bona debitoris \\
\hline 22 & [PP?] $\mathrm{k} \cdot \mathrm{Mal} \cdot \mathrm{GOR} \cdot \mathrm{a}$ & & non Iure postulant unde \\
\hline 23 & [et ? con]ss . & & si quidem debitoris tui ce \\
\hline
\end{tabular}

III. Corrected text and translation:

Presented below is a corrected text of the Vallicelliana fragments, showing the differences with Krüger's standard edition, but generally ignoring orthographic variants. Lacunae are only indicated for passages not attested also in other manuscripts. Substantive textual matters, principally regarding the headings and subscripts, are discussed in the succeeding section.

$$
\text { Folio } 1 \text { (= CJ 7,64,2-9) }
$$

Quod si cum de aetate quaereretur, implesse defunctum quartumdecimum annum ac per hoc iure factum') testamentum pronuntiauit, nec prouocasti aut post appellationis impletam causam ${ }^{2}$ ) destitisti, rem iudicatam retractare non debes. PP. xvi k. April. Alexandro A. II <et Marcello> conss.

III. Imp. Gordianus $\mathrm{A}$. Ingenuo. $\mathrm{Si}$, ut proponis, suspensa apud amplissimos ${ }^{3}$ ) iudices cognitione $e^{4}$ prouocationis, quam te ob id interposuisse ${ }^{5}$ ) dicis, quod decurio nominatus esses ${ }^{6}$ ), ad duumuiratum uocatus $\mathrm{es}^{7}$ ), manifestus ${ }^{8}$ ) est praeiudicium futurae notioni memoratorum iudicum fieri non potuisse. PP. k. Mar. S[a]b[ino et Venusto conss?].

Impp. ${ }^{9}$ ) Valerianus et Gallienus AA. et Valerianus nob. C. Iuliano. Cum magistratus datos iudices et unum ex his pronuntiasse proponas, non uidetur appellandi necessitas fuisset $^{10}$ ), cum sententia iure non teneat ${ }^{11}$ ). PP. k. Iul. Ae[milia]no et Basso conss. 
IIII. Impp. Carinus et Carus et Numerianus AAA. Domitiano. Certa ratione ${ }^{12}$ ) et fine et multare praesides possunt. Quod si aliter et contra legis ${ }^{13}$ ) statutum modum prouinciae praeses multam uobis inrogauerit, dubium non est id, quod contra ius gestum uideatur ${ }^{14}$ ), firmitatem non tenere et sine appellatione posse rescindi. PP. id. Ian. Caro et Carino conss.

[V]. Id. AAA. Germano. Cum non eo die, quo praeses prouinciae praecepit, iudex ab eodem datus pronuntiauerit, sed ductis ${ }^{15}$ ) diebus alieniore tempore sententiam ${ }^{16}$ ) dedisse proponatur ${ }^{17}$ ), ne ambages frustra interpositae prouocationis ${ }^{18}$ ) ulterius negotium protrahant ${ }^{19}$ ), praeses prouinciae superstitiosa appellatione submota ex integro inter uos cognoscet. PP. k. Dec. Carino et Numeriano conss.

[VI]. Impp. Diocletiano et Maximiano AA. Nicagorae. Venales sententias, quae ${ }^{20}$ ) in mercedem $\mathrm{a}^{21}$ ) corruptis iudicibus proferuntur, et citra interpositae prouocationis auxilium iam pridem a diuis principibus infirmatas ${ }^{22}$ ) esse decretum ${ }^{23}$ ) est. PP. $\mathbf{v} \mathbf{k}$. Ian. Diocletiano A. II. et Aristobulo conss.

VII. Id. AA. Constantio. Si pater tuus, cum decurio creareris, $<$ non $>24$ ) consensit et XV annos aetatis agis, aditus praeses prouinciae, si inhabilem te ad obeundum ${ }^{25}$ ) decurionatus honorem esse perspexerit ${ }^{26}$ ), quando huiusmodi aetati etiam praetermissa appellatione ${ }^{27}$ ) subueniatur, iniquam ${ }^{28}$ ) nominationem remouebit. PP. iiii k. Oct. ipsis IIII et III AA. conss.

VIII. Id. AA. et C. Rufino. Veteranis, qui in legione uel uexillatione ${ }^{29}$ ) militantes post uicesima ${ }^{30}$ ) stipendia honestam uel causariam missionem consecuti sunt, hononum $^{31}$ ) et munerum personalium uacationem concessimus. Huius autem indulgentiae [nostrae tenore remunerantes fidam deuotionem militum nostronum etiam prouocandi necessitatem remisimus.]

1) factu, Vall. $\quad{ }^{2}$ ) sic Vall. and R; post appellationem impletam causa, $\mathrm{Kr}$. (from C) 3) spensa amplissimos, Vall. 4) cognitiones, Vall. 5) obedienter posuisse, Vall. ${ }^{6}$ ) esse, Vall. ${ }^{7}$ ) uocatum est, Vall. ${ }^{8}$ ) minifestus, Vall. ${ }^{9}$ The numeral IIII is omitted, which affects later numerals. ${ }^{10}$ ) fuisse, Vall. "11) teneant, Vall. ${ }^{12}$ ) certatione, Vall. ${ }^{13}$ ) leges, Vall. ${ }^{14}$ ) uidetur, $\mathrm{Kr}$. ${ }^{15}$ ) seductis, Vall. ${ }^{16}$ ) sententia, Vall. ${ }^{17}$ ) proponantur, Vall. 18) fustra interposite pro[uoca] tione, Vall. ${ }^{19}$ ) protrahantur, Vall. ${ }^{20}$ ) qui, Vall. ${ }^{21}$ ) (sententi\}a, Vall. ${ }^{22}$ ) infirmatas, CR; infirmitas, Vall.; infirmas, $\mathrm{Kr} .{ }^{23}$ ) decertum, Vall. ${ }^{24}$ ) Omitted in Vall. ${ }^{25}$ ) adero eundem, Vall. ${ }^{26}$ ) prexerit, Vall. ${ }^{27}$ ) pretermissam appellationem, Vall. ${ }_{28}^{29}$ inquam, Vall. 25 ) legionem uel uexillationes, Vall. ${ }^{35}$ ) ui cesimam, Vall. ${ }^{31}$ ) onerum, $\mathrm{Kr}$. 


$$
\text { Folio } 2 \text { (= CJ 7,71,8,4-7,72,6) }
$$

(4) [Pari autem quantitate debiti inuenienda, dispari uero creditorum] numero, tunc amplior pars creditorum obtineat, ut, quod pluribus placeat, hoc statueretur. (5) Sin uero undique aequalitas mergat tam debiti quam numeri creditorum, tunc eos anteponi, qui ad humaniorem declinant ${ }^{32}$ ) sententiam non cessionem exigentes, sed indutias. (6) nulla quidem differentia inter hypothecarios et alios creditores ${ }^{33}$ ) quantum ad hanc electionem obseruanda ${ }^{34}$ ), in rebus autem officio iudicis partiendis suam uim singulis creditoribus habentibus, quam eis legum praestabit ${ }^{35}$ ) regula. (7) nullo praeiudicio creditorum cuidam ex quinquennii dilatione circa temporalem praescriptionem generando.

\section{[Titulus LXXII ?]}

De bonis auctoritate iudicis possidendis ${ }^{36}$ ) seu uenumdandis et de separationibus.

I. Imp. Antoninus A. Atticae. In bonis mortui potiorem esse causam legatariorum, qui eum utpote heredem conuenire potuerunt, quam eorum, quibus ipse legauit, manifestum est, cum prius legatum quasi aes alienum exigitur, legatum autem a mortuo relictum post debiti detractionem ${ }^{37}$ ) inducitur. PP. xv k. Iul. G[entiano] et Basso conss.

$<$ Il>. Imp. Gordianus A. Aristoni. Est iurisdictionis tenor promptissimus indemnitatisque remedium edicto praetoris creditoribus hereditariis demonstratum ut, quotiens separationem bonorum postulant, causa cognita impetrent. Praeoptabis ${ }^{38}$ ) igitur conuenientem $^{39}$ ) desiderii ${ }^{40}$ ) tui fructum, si te non heredem fidem secutum, sed ex necessitate ${ }^{41}$ ) ad iudicium eos prouocare demonstraueris. ${ }^{42}$ ) [PP. ]iii k. Feb. Gordiano A. et Auiola conss.

[III]. Id. A. Claudianae. Ex contractu ${ }^{43}$ ), qui cessionem rerum antecessit, debitorem contra iuris ${ }^{44}$ ) rationem conuenies ${ }^{45}$ ), cum eum aequitas auxilio exceptionis ${ }^{46}$ ) $\mathrm{mu}$ niat ac tunc demum iteratam ${ }^{47}$ ) possis desiderare conuentionem, cum tantum postea quaesiit, quod praesidem ad eius rei licentiam ${ }^{48}$ ) debeat promouere. [PP.] k. Mai. Gordiano A. [et ?con]ss.

[IIII]. Impp. Diocletianus et Maximianus AA. et CC. Clearchianae ${ }^{49}$ ). Inciuile est, quod postulas, ut unus ex cyrografariis creditoribus debitoris bona compellatur suscipere, satis <ceteris $>$ so ) eius creditoribus facturus. S. id. April. Byzantio AA. conss.

V. Id. AA et CC. Abidimo ${ }^{51}$ ). Si bona debitoris tui uacare constet ${ }^{52}$ ) et haec a fisco non agnoscantur, in possessionem ${ }^{53}$ ) eorum mitti te $a^{54}$ ) conpetenti iudice ${ }^{55}$ ) recte postulabis. S. xvii k. Ian. AA. ${ }^{56}$ ) conss.

VI. Id. AA. et CC. Agathemero. Pro debito creditores addici sibis7) bona debitoris non iure postulant unde si quidem debitoris tui ce[teri creditores pignori res acceperunt, potiores eos quam te chirographarium creditorem haberi non ambigitur.]

${ }^{32}$ ) declinat, Vall. ${ }^{33}$ ) hypothecarias et alios creditorum, Vall. ${ }^{34}$ ) observandam, Vall. ${ }^{35}$ ) prestauit, Vall. ${ }^{36}$ ) possidentis, Vall. ${ }^{37}$ Krüger's emendation; retractatione in Vall. and similarly in the other mss. ${ }^{38}$ ) Jtabis, Vall.; reportabis, Russardus. ${ }^{39}$ ) conueniente, Vall. ${ }^{40}$ ) desidesiderii, Vall. ${ }^{41}$ ) necessitatem, Vall. ${ }^{42}$ ) damonstrauerit, Vall. ${ }^{43}$ ) contractum, Vall. ${ }^{44}$ ) iurem, Vall. ${ }^{45}$ ) conueniens, Vall. ${ }^{45}$ ) excessionis, Vall. ${ }^{47}$ ) iterate, Vall. ${ }^{48}$ ) licentia, Vall. ${ }^{49}$ ) clearcine, Vall. ${ }^{50}$ ) Omitted in Vall. ${ }^{51}$ ) Abydonio, $\mathrm{Kr}$. ${ }^{52}$ ) cognoscent, Vall. ${ }_{53}^{5}$ ) possessione, Vall. ${ }_{54}^{5}$ ) ea, Vall. (for 'te $a^{\prime}$ ) ${ }_{55}$ ) iudicem, Vall. ${ }^{56}$ ) cc, Vall. ${ }^{57}$ ) sui, Vall. 


\section{CJ 7,64}

2] ... But if, when the issue of age was raised, he (the judge) ruled that the deceased had completed his fourteenth year and this was the reason the will was lawfully made, and you did not appeal or stopped after the completed hearing of the appeal, you must not resurrect the matter judicially settled. Posted up on the sixteenth day before the Kalends of April, in the consulship of Alexander Augustus (for the second time) <and of Marcellus>.

3] The emperor Gordian Augustus to Ingenuus. You state that you were summoned to the duumvirate, while the hearing of an appeal before the most distinguished judges was in suspension, an appeal which you say you had lodged for this reason, that you had been nominated as a decurion. If so, it is clear that there could not be any prejudice to the future ruling of the above-mentioned judges. Posted up on the Kalends of March, in the consulship of Sab[inus and Venustus?].

4] The emperors Valerian and Gallienus Augusti and Valerian the most noble Caesar to Julianus. Since you state that the magistrates were appointed as judges and only one of them has given a verdict, there does not appear to have been the need for an appeal, since the sentence is not legally valid. Posted up on the Kalends of July, in the consulship of Aemilianus and Bassus.

5] The emperors Carinus, Carus and Numerianus Augusti to Domitianus. Governors are able to levy fines under specific circumstances and within fixed limits. But if the governor of the province has imposed a fine upon you otherwise and contrary to the established measure of the law, there is no doubt that what appears done contrary to law has no validity and can be revoked without an appeal. Posted up on the Ides of January, in the consulship of Carus and Carinus.

6] The same Augusti to Germanus. Since on the day as laid down by the governor of the province the judge appointed by him did not give his verdict, but he is stated to have given the verdict at another time several days later, the governor of the province will hear the case between you from the beginning, quashing the outstanding appeal, so that the meanderings of a vainly lodged appeal may not protract the matter any further. Posted up on the Kalends of December, in the consulship of Carinus and Numerian.

7] The emperors Diocletian and Maximian Augusti to Nicagoras. Trafficked verdicts, which are given by corrupt judges for a price, have long since been decreed to be invalid by the divine emperors even without the assistance of an intervening appeal. Posted up on the fifth day before the Kalends of January, in the consulship of Diocletian Augustus (for the second time) and of Aristobulus.

8] The same Augusti to Constantius. If, when you were made a decurion, your father did not consent and you are 15 years of age, approach the governor of the province, and, if he should see that you are incapable of an office such as the decurionate, he will revoke the unfair nomination, since there is help for this age-group even with the appeal omitted. Posted up on the fourth day before the Kalends of October, in the consulship of the Augusti themselves for the fourth and third times respectively.

9] The same Augusti and Caesars to Rufinus. To veterans, who have gained honourable or medical discharges after 20 years serving in legion or vexillation, we have granted exemption from office and personal munera. Also, in rewarding the faithful 
devotion of our soldiers by the tenor of this our indulgence, we have removed the need for their making an appeal.

$$
\text { CJ 7,71,8,4-7 }
$$

(4) [If the amount of the debt is equal, but the number of creditors unequal], then the greater number of creditors is to win, so that what the majority wants is to be applied. (5) But if there is matching equality, both of the debts and in the number of creditors, those are to be preferred, who incline to the more humane view, imposing not a cession of property but a period of grace. (6) There is to be no difference in making the choice between secured creditors and the others. But in the apportioning of property by the office of the judge, each creditor is to have the strength of claim, that the legal rules grant him. (7) Regarding the calculation of periods of prescription, there is to be no prejudice to any of the creditors from the five-year postponement.

$$
\text { CJ } 7,72
$$

On goods possessed or sold by the authority of a judge and on separations (of property).

1] The emperor Antoninus Augustus to Attica. In relation to the goods of the deceased, it is clear that the case of those legatees is stronger, who can sue him as heir, than of those, to whom he himself left things, since in the first case the legacy is exacted like a debt, but the legacy left by the deceased is applied only after the deduction of the debt. Posted up on the fifteenth day before the Kalends of July, in the consulship of Gentianus and Bassus.

2] The emperor Gordian Augustus to Aristo. The most ready purpose of jurisdiction and remedy for indemnity is set out by the praetor's edict for the creditors of an inheritance, so that they should successfully obtain a judgement, whenever they bring a motion for the separation of the goods. Therefore you will choose an outcome matching your wish, if you show that you did not rely on the faith of the heirs, but summoned them to court by necessity. [Posted up] on the third(?) day before the Kalends of February, in the consulship of Gordian Augustus and of Aviola.

3] The same Augustus to Claudiana. Suing a debtor on a contract, which precedes the cession of property, is against the rule of law, since equity protects him by the assistance of a defence. But then you can in due course request to sue a second time, if he should later acquire so much property as to force the governor to grant licence for this. [Posted up] on the Kalends of May, in the consulship of Gordian Augustus [and of ?].

4] The emperors Diocletian and Maximian Augusti and the Caesars to Clearchina. What you ask is not lawful, that one of the unsecured creditors should be compelled to take over the debtor's property and then satisfy his other creditors. Written on the Ides of April at Byzantium, in the consulship of the Augusti.

5] The same Augusti and Caesars to Abidimus. If it is agreed that your debtor's goods are ownerless and these have not been claimed by the fiscus, you will be correct in asking that you be put in possession of them by a competent judge. Written on the seventeenth day before the Kalends of January in the consulship of the Augusti.

6] The same Augusti and Caesars to Agathemerus. The creditors are not lawfully asking that the debtor's goods be adjudged to them. And so, if other creditors of your debtor accepted property in pledge, it is absolutely clear that they are deemed to have a stronger claim than you as an unsecured creditor. 
IV. The headings and the subscripts:

CJ 7,64,2 [F 1r col. 1]

Subscript: PP. xvi k. April. Alex. A. II conss. (1 $7^{\text {th }}$ March 226)

This subscript is new. The second consul (Marcellus) is missing, although the plural consular abbreviation still stands in the subscript as a fixed repeated element. Honoré previously assigned this text to Herennius Modestinus (his secretary no. 8) ${ }^{9}$ ), proposing for him a principal period in office Oct. 223-Oct. $225^{10}$ ). However, he also envisaged a possible extension to March 226 and a 'hand-over' period at this time ${ }^{\prime \prime}$ ). Perhaps, therefore, his attribution to Modestinus can be maintained.

CJ 7,64,3 (numbered IID) [F $1 \mathrm{r}$ col. 1]

Heading: Imp. Gor. A. Ingenuo.

Subscript: PP. k. Mar. S[a]b[ino et Venusto? con]ss (1* March 240?)

The subscript is new. Although the diurnal date is clear, the consular date has to be deduced from the upper remains of only two letters, the top of a high curve and the top of a tall descender. Of the consules priores for the reign of Gordian III, Sabinus is the only one who would seem to match these traces ${ }^{12}$ ). However, Honoré assigned this text to his secretary no, 13, with a period in office from July 241 to July $246^{13}$ ).

CJ 7,64,4 [F lr col. 2]

Heading: Impp. Valer. [et Gallien.] AA. et Val. N[ob C.] Iuliano.

Subscript: PP. k. Iul. Ae[milia]no et Basso conss. (1st July 259)

There is no trace of a numeral against the heading, and it does not seem to have been lost in the trimming of the parchment, since the numeral against $\mathrm{CJ} 7,64,5$ is incorrectly given as IIII. The heading, though incompletely preserved, is easily restored to match other manuscript witnesses. The Code versions of the Valerianic colleges are the only ones to grant their Caesars (frequently if inconsistently) the style nobilissimus ${ }^{14}$ ). It is, of course, standard in contemporary formal texts ${ }^{15}$ ). The subscript is new, the consulship being clearly that of Aemilianus and Bassus (259).

CJ 7,64,5 (numbered IIII) [F 1r col. 2]

Heading: Impp. Carinus et C[arus] et Numed. AAA. Do[mi]tiano.

Subscript: PP. id. Ian. Ca[ro et Carino conss.] (13th January 283)

Although numbered IIII, this is clearly in error because of the omission of a number against the preceding constitution. The imperial college of the heading is clear, de-

9) Tony Honoré, Emperors and Lawyers, $2^{\text {sd }}$ ed., Oxford 1994, 132 n. 801.

10) Honoré (n. 9), 104-107 and 190.

11) Honoré (n. 9), 104.

12) The consuls are Pius (238), Gordian (239), Sabinus (240), Gordian (again; 241), Atticus (242), Arrianus (243), Peregrinus (244). See A. Degras si, I fasti consolari dell'impero romano, Rome 1952, 66-67.

13) Honoré (n. 9), 133 n. 809.

14) Thus CJ $2,3,15 ; 2,4,11 ; 3,28,16 ; 4,26,6 ; 4,35,8 ; 7,16,6 ; 7,71,3$. The only tetrarchic examples are CJ 1,18,5 (First Tetrarchy), 3,12,1 and 6,9,7 (Second Tetrarchy); cf. Collatio 6,4 and 15,3. See S. Corcoran, The Tetrarchy: policy and image as reflected in imperial pronouncements, in: D. Boschung and W. Eck (eds.), Die Tetrarchie: Ein neues Regierungssystem und seine mediale Pråsentation, Wiesbaden 2006, $44-45$.

15) E. g. IGLS VII 4028 (Valerianus Caesar); Monumenta Asiae Minoris Antiquae (MAMA) X 114 (Philippus Caesar); P.Lips. 44, now Chartae Latinae Antiquiores XII 526 (First Tetrarchy); L'Année Epigraphique (AE) 2002, 1293 (Maximinus Caesar). 
spite some disorder. It should of course read Impp. Carus et Carinus et Numerianus. The incomplete subscript confirms that printed in the only other source to preserve it, viz. Russardus' edition of 1560 . Two other manuscripts, Pistoia (P) and Paris (L), give only $P P$. Honoré assigned this text as his earliest to secretary no. 16A, serving Carus in the east, and cites this text in full as an example of that magister's laboured style $\left.{ }^{16}\right)$.

CJ 7,64,6 [F lv col. 1]

Heading: [Id. AAA. Germ] ano.

Subscript: PP. k. Dec. [Cari]no et Num. conss. (1 st December 284)

Although the heading only preserves "[ . . . ]ano", the emperors and recipient can easily be restored as Idem AAA. (i.e. Carus, Carinus and Numerianus) to Germanus ${ }^{17}$. The subscript is entirely new, giving the date of posting as 1 st December 284. The consulship must be restored as that of Carinus and Numerian in $284^{18}$ ). Tony Honoré identified the author as magister libellorum no. 16A, serving first Carus, then Numerian $^{19}$ ). Since Diocletian had succeeded Numerian on 20 th November 284 , following the latter's mysterious demise, this is his earliest known rescript ${ }^{20}$ ). Given that $\mathrm{Nu}$ merian was dead for some time before his decomposing corpse was discovered, it is unlikely, even if we suppose the loss of a sizeable numeral before the ' $k$.', that this rescript could be pushed back in time into Numerian's reign, although it might have been already written, awaiting his signature. That the magister of Carus and Numerian continued to serve Diocletian, at least for a while, is perfectly plausible. Judging by Diocletian's actions after the death of Carinus the following year, conciliation of the officials of the previous emperor seems his policy. Carinus's praetorian prefect and fellow consul for the year, Aristobulus, remained prefect and continued as consul, with Diocletian now as his colleague ${ }^{21}$ ). So, aside from the violent elimination of Aper by Diocletian's own hand, continuance in post for previous office-holders is in character.

16) Honoré (n. 9), 146-147.

17) The members of imperial colleges in headings do not necessarily accurately mirror historical reality. For instance, all rescripts of 293 include the Caesars, even those from January and February before their appointment on $1^{\text {st }}$ March.

18) On this consulship, see R. Bagnall et al., Consuls of the Later Roman Empire, Atlanta 1987, 102-103.

19) Honoré (n. 9), 180 n. 551.

20) For the date of Diocletian's accession, firmly attested by Lactantius and the Beatty Panopolis Papyri, see T. D. Barnes, The New Empire of Diocletian and Constantine, Cambridge/MA 1982, 4 and D. Ki enast, Römische Kaisertabelle, $2^{\text {nd }}$ ed., Darmstadt 1996, 266, plus J. D. Thom as, Diocletian's birthday and date of accession: P. Mich. Inv. 5298a reconsidered, in: ZPE 128 (1999) 161-164. For the murky circumstances of Numerian's death and their modern interpretations, see H. W. B ird, Diocletian and the deaths of Carus, Carinus and Numerian, Latomus 35 (1976) 123132; T. B. Barnes, Constantine and Eusebius, Cambridge 1981, 4-5; S. Will ia ms, Diocletian and the Roman Recovery, London 1985, 32-38; A. K. Bow man et al. (eds.), The Cambridge Ancient History XII, $2^{\text {nd }}$ ed., Cambridge 2005, 57-58 and 6869; and S. Mitchell, A History of the Later Roman Empire AD 284-641, Malden/ MA 2007, 47-49.

21) Barnes (n. 20), 97 and Bagnall (n. 18), 104-105. 
CJ 7,64,7 [Folio Iv col. 1]

Heading: [Imp]p. Diocl. et Max. [AA.] Nicagores.

Subscript: PP. v [k.? I]an. Diocl. II et Aristo[bulo conss.] (28th December 285)

$\mathrm{P}$ and $\mathrm{L}$ give the name as Nicagori, while the Summa Perusina prefers Nicanor ${ }^{22}$ ).

Krüger prints Nicagorae. The version here, despite the grammatical inaccuracy, seems to confirm his guess. The gender of the recipient cannot be determined from the rescript itself. However, the male form, Nicagoras, is far more common than the female, Nicagora (Nicagore) ${ }^{23}$ ).

The date was already partially preserved in the Pistoriensis, giving the consulship for 285 , but with the day unreadable, otherwise given in a conjoining text as $K$. Ian. (CJ 6,34,2). Both texts as part of a single rescript were assigned by Honoré to his no. 17 (Gregorius) on $1^{\text {st }}$ January 285, while still serving Carinus in the West ${ }^{24}$ ). Much of the Vallicelliana subscript is only partly preserved as a result of the trimming of the parchment, and has to be restored by comparison with the other witnesses, although even the most uncertain point, the month [I]an., is likely to be correct. However, the numeral $V$ is absolutely clear on the previous line. Usually a missing numeral before the Kalends makes little real difference to a date, only a few days, at most a couple of weeks. But January is different, since two different Kalends are in question. Thus $v k$ Ian. from the new subscript gives $28^{\text {th }}$ December 285. Acceptance of this date should also mean emendation of CJ 6,34,2. The effect of this is to leave only one rescript (CJ 4,20,4) assigned by Honoré to no. 17 before the summer of 285 to suggest that he had ever served Carinus in the west, before starting service with Diocletian.

As regards the main text of the rescript, the Vallicelliana Infirmitas is incorrect, but reflects the trend of the other manuscripts, which have variations on infirmitas/ atas. Kriger printed infirmas, but perhaps infirmatas was the original reading as at CJ $1,18,4$.

CJ 7,64,8 (numbered VII) [Folio Iv col. 2]

Heading: I[d. AA. Constantio].

Subscript: PP. iiii k. Oct. ipsis IIII et III AA. conss. (28th September 290)

The heading of this text is mostly missing here (only part of the elongated descender of the " $\Gamma$ " can be seen), but it is known from the rest of the tradition. The subscript date is new, but uncontroversial, reproducing a very common style for this year in the Code and other legal sources ${ }^{25}$ ). No other rescripts are dated to this day, although three belong to 29 September ${ }^{26}$ ). From the date, the magister libellorum who wrote the text must be no. 19 (Charisius), although Honoré did not detect in it any positive signs of style ${ }^{27}$ ).

${ }^{22}$ ) For the Summa Perusina reference, see G. E. Heimbach, Anekdota II, Leipzig 1840, 124 and F. Patetta, Adnotationes Codicis Domini Iustiniani (Summa Perusina), BIDR 12 (1900), 251.

$\left.{ }^{23}\right) 195$ versus 26 according the on-line Search II of the Lexicon of Greek Personal Names (covering volumes I, Ila, IIIa, IIIb, IV and Va) [http://www.lgpn.ox.ac.uk], checked on 8. Sept. 2008.

24) Honoré (n. 9), 147-148.

25) Bagnall (n. 18), 114

26) CJ $3,44,12 ; 6,37,15 ; 7,43,8$.

27) Honoré (n. 9), 181 n. 555. 
CJ 7,64,9 (numbered VIII) [Folio 1v col. 2]

Heading: Id. AA. et CC. Ruphino.

The folio breaks off before the subscript. The heading however confirms the recipient as Rufinus. In his edition of this text, Krüger prints onerum over honorum as similarly at CJ 4,12,3. However, the conjunction of honores and munera as two complimentary but separate technical terms is far more common in the third-century rescripts ${ }^{28}$ ). Note in particular the very similar text CJ 10,55,3: Veteranis ita demum honorum et munerum personalium uacatio iure conceditur, si post uicesimum annum militiae, quam in legione uel uexillatione militauerunt, honestam uel causariam missionem consecuti esse ostendantur. Onus is a looser synonym for munus ${ }^{29}$ ), and documentary sources show it used (like munera) in contrast to honore ${ }^{30}$ ). honorum must, therefore, be the correct reading here. Even in the Florentine Digest editors have seen miscopying, with onus for honor in Digest 50,1,18.

CJ 7,71,8 [F 2r col. 1]

The subscript for this constitution of Justinian to John the Cappadocian, absent in the rest of the tradition, has been lost here also in the trimming of the parchment. Judging by the space needed for the missing text in CJ 7,72,2 at the bottom of col. 2, the subscript, if present, would have covered two lines.

CJ 7,72,1 [F 2r col. 2]

Heading: Imp. Ant. A. Attic[e].

Subscript: PP. xv k. Iul. G[entiano?] et Basso conss. (17th June 211)

Although very hard to read, it is possible that the numeral ' $I$ ' stood against the heading. Note that not all of the recipient's name is preserved, but Attica is surely correct, as per Krüger ${ }^{31}$ ). The subscript is new, but of the first consul's name only a 'c' is readable before the trimmed edge of the parchment. Given that the second consul's name is clearly Bassus, the consulship of 211 appears to be the only one to match surviving traces, if the first consul was spelled Centianus. Honoré does not attribute this text to any secretary ${ }^{32}$ ). In the text of the rescript, the retractatione matches the trend of the other manuscript witnesses, but Krüger's detractionem (deduction) must be correct. Retractatio and indeed detractatio both mean refusal and would make no sense in this passage.

CJ 7,72,2 [Folio 2r col. 2-2v col. 1]

Heading: Imp. Gor. A. Aristoni.

Subscript: [PP. ]iii k. Feb. Gor. A. [et A]biola conss. (30th January 239)

This subscript is new. The trimming of the parchment means that it is impossible to know whether there were other numerals before 'iii', but the date can only be out by a few days, if at all. The second consul's name only survives as 'biola' but is, of course,

${ }^{28}$ ) CJ $5,71,16 ; 7,62,7 ; 8,47,7 ; 10,32,5 ; 10,39,3 ; 10,40,3 ; 10,41,1 ; 10,55,2 ; 10,57,1$; $10,64,1 ; 10,65,3 ; 10,70,1$; CTh 12,1,5; Digest $50,5,10,4$ and $50,5,12,1$. Note also the title de muneribus et honoribus at Digest 50,4 .

${ }^{29}$ ) Thus the rhetorical tripling muneribus et oneribus et obsequiis at CTh 13,5,7.

30) See G. A. Cecconi, Governo imperiale e élites dirigenti nell'Italia tardoantica: problemi di storia politico-amministrativa (270-476 d. C.), Como 1994, 174 175.

31) The Summa Perusina gives Atticia (Heimbach [n. 22], 125).

32) Honoré (n. 9), 132, n. 798. 
Aviola. The year is 239. This matches Honore's attribution of this text to his secretary no. 12 , in office March 238 to June $241^{33}$ ).

CJ 7,72,3 [Folio 2v col. 1]

Heading: [Id.] a. claudeane.

Subscript: [PP.?] k. Mai. Gor. A. [et ignoto? con]ss. (1st May 239 or 241)

The name of the recipient, Claudiana, matches the rest of the tradition. The subscript is new. It is difficult to tell if a numeral was present in the part missing before $k$. mai., but the diurnal date cannot be far wrong. Of the second line of the subscript, only the superscript abbreviation stroke from conss. survives. Gordian III was consul twice, for the first time with Aviola in 239 as in the previous rescript, for the second time with Pompeianus in 241. There is no way of deciding which of these two is correct. Both dates fall within the period in office of Honoré's secretary no. 12, to whom he attributes this text ${ }^{34}$ ).

CJ 7,72,4 [Folio 2v col. 2]

Heading: I[mpp. Diocl. et Max.] AA. et C. Clearcine.

Subscript: S. id. Apri. Biza. AA. conss. (13th April 293, at Byzantium)

The correct form of the recipient's name is probably Clearchiana, as Krüger prints following the Summa Perusina's Clearciana ${ }^{35}$ ). Clearchiana is certainly the most plausible form for such a Greek name with a Latin ending, but is otherwise unattested ${ }^{36}$ ). The subscript is new, and both clear and uncontroversial. It is one of several texts issued at Byzantium on this date ${ }^{37}$ ). The author of this text was identified by Honore as Hermogenian, in office as magister libellorum throughout 293 and 294, although apparently solely on the basis of date (inferred from the following dated rescript) ${ }^{38}$ ). Because Hermogenian gathered the rescripts he wrote into the Hermogenian Code, it is notable that most carry the date that the emperor signed them (data or scripta or subscripta). Earlier texts taken from the Gregorian Code more routinely have the date of posting up (proposita) outside the emperor's residence. However, this contrast cannot be pushed too far. Rescripts in the Justinian Code may have been edited by the commissioners, and Hermogenian constitutions from outside the Code exhibit a degree of inconsistency ${ }^{39}$ ). Whatever this may reveal about the nature of the original Gregorian and Hermogenian Codes, it is quite clear that this and the succeeding text correctly reflect Justinian Code practice.

33) Honoré (n. 9), 117 n. 569 and 133 n. 808.
34) Honoré (n. 9), 117 n. 565 and 133 n. 808 .
35) Other versions transmitted are Clearcina (M; as Vall.), Cleartina (C ), Claretia (R). For the Summa, see Heimbach (n. 22), 125 and Patetta (n. 22), 255.

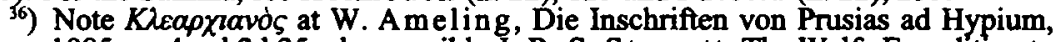
Bonn 1985, no.4 col.2 1.25; also possibly J.R. S. Sterrett, The Wolfe Expedition to Asia Minor (Papers of the American School of Classical Studies at Athens 3), Boston 1888,185 no. 304. For the formation of such names, see I. Kajanto, The Latin Cognomina, Helsinki 1965, 109-110. -iamus names are the subject of current research by Th. Corsten, Acts of the $13^{\text {t }}$ International Congress of Greek and Latin Epigraphy, Oxford, 2-7 September, 2007: Summary Papers, Oxford 2007, 60.

${ }^{37}$ CJ 5,70,4;6,42,22; 7,60,2;8,39,2 (all Id. Apr. at Byzantium); CJ 3,19,1; 3,32,13; 4,19,9; 6,2,10; 7,32,6 (Id. Apr. alone).

${ }^{38)}$ Honoré (n. 9), 64 n. 315.

39) See the discussion by M. U. Sperandio, Codex Gregorianus: origini e vicende, Naples 2005, 149-159. 
CJ 7,72,5 (numbered V) [Folio 2v col. 2]

Heading: Id. AA. et CC. Abidimo.

Subscript: S. xvii k. Ian. CC. conss. (16 ${ }^{\text {th }}$ December 294 [293])

Kriger prints the recipient's name as Abydonius, following Heimbach's reading of the Summa Perusina (as with the previous rescript), although Blume and Patetta read Abydomus, and the other manuscripts give Abidimus or Abdimus ${ }^{40}$ ). Despite its classical look, Abydonius does not derive from Abydos (which gives Abydenus), and is only obscurely attested in some grammatical or geographical works (derived from a Macedonian place-name, Abydon) ${ }^{41}$ ). It has not been found as a personal name. Abidimus might be a comption, indeed, of Abydenus, or of Avidius or Avitius ${ }^{42}$ ). However, something beginning in $A b d$ suggests Latinisation of a Semitic word form $\left.(A b d=\text { slave })^{43}\right)$. Indeed, Abdimus is attested in the mediaeval Latin tradition of the Cassiodoran version of Josephus's Antiquities ${ }^{44}$ ). In his original work, Josephus gives an account of the relations between Solomon and Hiram, king of Tyre, in particular their exchange of riddles, quoting verbatim passages from two historians, Menander of Ephesus and Dios (Ant. Jud. 8,144-9) ${ }^{45}$ ). An almost identical account is given in Against Apion (1,112-20), except that Dios is quoted before Menander ${ }^{46}$ ). In Against Apion, the person credited with solving the riddles is named by Dios (Ap. 1,115)

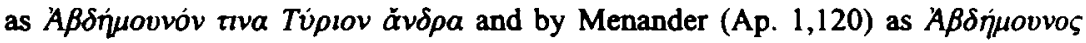

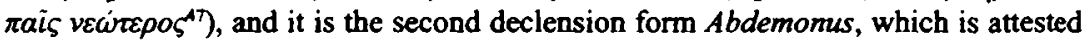

10) For the readings, see Krüger's apparatus ad loc., with He i mbach (n. 22), 125 and Patetta (n. 22), 255.

41) W. Pape/G. Benseler, Wörterbuch der griechischen Eigennamen, $3^{\text {rd }}$ ed., Brunswick 1884 [repr. Graz 1959], 2; M. Billerbeck, Stephani Byzantii Ethnica, vol. I: $A-\Gamma$, Berlin 2006, 26, A16 (Abydos) and A17 (Abydon).

12) E. g. B. Lörincz, Onomasticon provinciarum Europae Latinarum I, rev. ed., Budapest 2005, 16: Abidius, Abidianus. $1-3$.

43) E. g. K. Jongeling, North-African Names from Latin Sources, Leiden 1994,

4) The Cassiodoran translation was in 22 books (the last two books being Against Apion I-II). Since there were already two fourth-century Latin versions of the Jewish War (Rufinus, Hegesippus), only the Life among Josephus's works remained without a Latin version in the middle ages. See Cassiodorus, Institutes $1,17,1$ and $\mathrm{H}$. Schreckenberg/K. Schubert, Jewish Historiography and Iconography in Early and Medieval Christianity, Assen 1992, 76-77.

45) Menander: Ja coby, FGrH IIIC, Leiden 1958, 788-795, no. 783. Dios: A. Ka Idellis, Dios (785), in: I. Worthington (ed.), Brill's New Jacoby, Leiden 2008: accessed on-line 14 February 2008.

16) For the overlap between the two works, see P. Spilsbury, Contra Apionem and Antiquitates Judaicae: points of contact, in: L. H. Feldman and J. R. Levi ison (eds.), Josephus' Contra Apionem: Studies in its Character and Context with a Latin Concordance to the Portion Missing in Greek, Leiden 1996, 351.

47) Thus the edition of B. Niese, Flavii Iosephi Opera V, Berlin 1889, 20-21; similarly in vol. I of the Loeb edition (H. St.-J. Thackerary, Josephus: The Life, Against Apion, Cambridge/MA 1926, 208-210); cf. J. M. G. Barclay, Flavius Josephus, Translation and Commentary vol. 10: Against Apion, Leiden 2007, 72-74. Th. Reinach's Budé (Flavius Josèphe, Contre Apion, Paris 1930, 23-24) rejects the manuscript authority in favour of the name $A \beta \delta \eta \dot{\eta} \omega \nu$ from the tradition of the Antiquities. Note that the version from the Against Apion is the source for the quotation used in Eusebius's Chronicle, surviving only in the Armenian translation, or as incorporated into Syncellus. See A. Schoene, Eusebii Chroniconum Liber Prior, Berlin 1875, 115-118; A. A. Mosshammer, Georgii Syncelli Eclo- 
in both instances in the Latin Against Apion ${ }^{48}$ ). In the Antiquities, Dios (Ant. Jud.

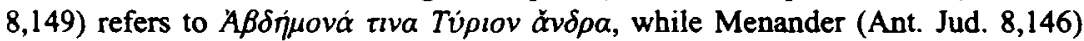

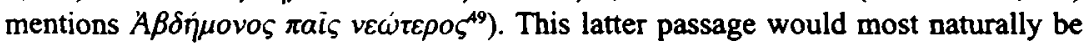
taken, by analogy with the form of the name in Dios, as a $3^{\text {rd }}$ declension genitive, but it seems more often taken as a second declension nominative (as in the Against Apion quotation $)^{\text {so }}$ ). Unfortunately, the critical edition of the Latin Antiquities stalled after one volume and did not reach Book Eight ${ }^{51}$ ), but the apparatus criticus to the Niese and the Nodet editions both cite the Latin tradition ${ }^{52}$ ) and make it clear that in the Dios quotation the name is Abdimus, but Abdimonis in the Menander ${ }^{33}$ ), thus treating it as a genitive $\left.{ }^{54}\right)$. Further, this passage is quoted verbatim by William of Tyre, and here a name is added to the Menander passage to give Abdimus, Abdaemonis filius, on the reasonable basis that the person named in the Dios passage (Abdimum quemdam Tyrium) should fill the place of the unnamed son of Abdemon in Menander ${ }^{55}$ ). Despite the confusions of the name in both the Greek and Latin traditions of Josephus's quotations of Menander and Dios, it is clear that an original Phoenician name, 'bdhmn (slave of Hammon) ${ }^{56}$ ), was rendered variously into Greek as $A \beta \delta \dot{\eta} \mu \omega v$, $A \beta \delta \dot{\eta} \mu o v v o s$

ga chronographica, Leipzig 1984, 214 and W. Adler/P. Tuffin, The Chronography of George Synkellos, Oxford 2002, 266; J. Karst, Eusebius Werke 5: Die Chronik aus dem Armenischen übersetzt mit textkritischem Commentar, Leipzig $1911,54$.

48) C. Boy sen, Flavii Iosephi opera: ex versione Latina antiqua, pars 6, De ludaeorum vetustate sive contra Apionem libri II (CSEL 37), Vienna 1898, $25-27$.

${ }^{49}$ ) B. Nies e, Flavii Iosephi Opera II, Berlin 1885, 208-209; similarly in the Loeb edition vol. V (H. St.-J. Thackerary/R. Markus, Josephus: Jewish Antiquities Books V-VIII, Cambridge/MA 1934, 650 [= reprint 1998, vol. VII, 294]); and the Budé: E. Nodet, Flavius Josèphe, Les Antiquites Juives IV, Paris 2005, 45-46; cf. C. $\mathrm{Begg} / \mathrm{P}$. Spilsbury, Flavius Josephus, Translation and Commentary vol. 5: Judean Antiquities 8-10, Leiden 2005, 40-41.

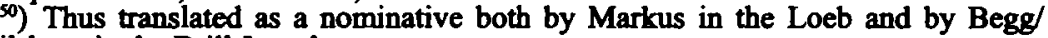
Spilsbury in the Brill Josephus.

s1) F. B latt, The Latin Josephus I: Introduction and Text, The Antiquities Books I-V, Copenhagen 1958.

$\left.{ }^{52}\right)$ See the editions cited in $n$. 49. Note that there is a sixth century papyrus manuscript in the Ambrosian Library (Cimelio MS 1 = Codices Latini Antiquiores III 304) covering 5.334-10.204 and so including our passage, see Blatt, The Latin Josephus (n. 51), 26-27. Given the fulsome praise heaped on the manuscript by $\mathrm{Niese}$ (Flavii Iosephi Opera I, Berlin 1887, XXVIII), it is likely that its readings are the ones reflected in his (and later Nodet's) apparatus.

${ }^{53}$ ) A check of three sample manuscripts from the British Library produced the following readings: Harleian 3699 (XVs.; B latt, The Latin Josephus [n. 51], 38-39 no. 31) fo. $140 \mathrm{v}-$ Abdimonis filius iuuenculus (Menander) and abditum quendam tyrum (Dios); Harleian 3691 (XVs.; Blatt, The Latin Josephus [n. 51], 41-42 no. 40) fo. 89r-abdimonis filius iuuenculus (Menander) and per Abdimum guendam tirium (Dios); Harleian 3883 (XII/XIIIs.; B latt, The Latin Josephus [n. 51], 53 no. 72) fo. 119v - abdimonis filius iurenculus (corrected from abdemonis) (Menander) and quendam tyrium per abdimum (Dios).

${ }^{4}$ ) Note that the Armenian version of Eusebius (deriving from Against Apion) also takes the name in the Menander as a genitive, as noted in Niese's apparatus and so translated by Karst and Schoene (see $n$. 47).

${ }^{55}$ ) Willelmus Tyrensis, Chronicon 13.1 (ed. Huygens, CCCM 63, Turnhout $1986,586)$.

${ }^{56)}$ The god is Baal-Hammon, not the Egyptian Amon. See F. Briquel-Chaton- 
and $A B \delta \eta \dot{\eta}$ vo $^{57}$ ), and that Abdimus and Abidimus, in addition to Abdemonus or $\mathrm{Ab}$ demon, are plausible Latin renditions of the same. Thus Abidimus, the reading of the Vallicelliana and the other Code manuscripts, must here trump Abydonius, Krüger's choice.

The subscript is not new, but otherwise transmitted as $x v i i k$. Ian. aa conss. The $S$ (cripta) of the Vallicelliana is a correct supplement. However, the consular date of the Caesars (294) must be wrong, since CJ 7,72,7 was issued on the $1^{\text {s }}$ December 294, and the texts are supposed to be in chronological order. The correct year is 293 ( $A A$. conss.). Honore assigned the text to Hermogenian, but apparently from the date alone, not from any detectable signs of style ${ }^{58}$ ). It is one of several texts issued on the same day from Sirmium.

CJ 7,72,6 (numbered VI) [Folio 2v col. 2]

Heading: Id. AA. et CC. Agathemoro.

The inscription preserves the recipient's name in an almost correct form, which was probably Agathemerus (as printed by Krüger) ${ }^{59}$ ).

London

Simon Corcoran

net, Les relations entre les cités de la côte Phénicienne et les royaumes d'Israel et de Juda (Studia Phoenicia XII), Leuven 1992, 57.

${ }^{57}$ ) Other examples of this name in Greek are attested at Diodorus Siculus 14,98,1 and Sammelbuch V 7637.

s8) Honoré (n. 9), 64 n. 315.

59) 109 examples in the online LGPN (n. 23), checked 8. Sept. 2008. 